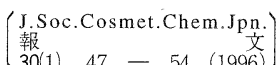

皮膚洗浄における物理洗浄粒子の機能と設計†'

\author{
浜田博一, 梶原 泰, 有沢正俊 \\ 花王株式会社 花王研究所 $\dagger^{2}$
}

\begin{abstract}
近年物理洗浄力を付加したスクラブ洗顔料は注目を浴びているが，スクラブの明確な機能を示唆した 報告はまだない。そこで我々は種々の研究によりスクラブ粒子の洗浄機能が皮膚細部における洗浄力を 高めることであり，特に皮溝中の污れを分散除去する効果があることを見いだした。

また，洗浄力とスクラブ粒子の関係を調べたところ，洗浄力を最大に発揮するには，皮虐と同等以上 の弾性率が必要なこと $\left(10^{7} \mathrm{dyne} / \mathrm{cm}^{2}\right.$ 以上), 粒径は皮溝の起伏，毛穴の大きさと同程度であること(200 $\sim 350 \mu \mathrm{m}$ )，また一定皮膚面積当たり，ある個数以上の粒子数が必要なこと(約 100 個 $\left./ \mathrm{cm}^{2}\right)$ がかった。

そして, 皮膚と同等の弾性率を持つスクラブ粒子 $\left(10^{7} \mathrm{dyne} / \mathrm{cm}^{2}\right)$ は皮虚に対してマイルドで皮膚へ の刺激が少なく，長期連用可能なスクラブ郕であることを確認した。
\end{abstract}

\section{1. 緒言}

物理的力で皮膚を洗浄する方法は古来より種々 知られているが，清潔志向の高まっている近年， 物理洗浄機能を付与したスクラブ洗顔料が注目さ れている。このようなスクラブ洗顔料に使用され ているスクラブ粒子は, 通常アーモンドミール, オートミール，アプリコット，クルミ，おが屑等 の天然植物素材, シリカ, ベントナイト, 酸化ア ルミニウム, 炭酸塩等の無機素材, ポリエチレ ン，ポリスチン等の合成高分子素材が知られて いる。

一般にスクラブ洗顔料の使用者は，にきびの予 防，毛穴や皮溝の污れ除去，脂浮き防止等を目的 として使用している。

しかし，一方では上記で挙げたスクラブ粒子の 肌への刺激を理由に中止する場合があり，また肌 への負担を考慮して間欠的に使用している場合も 見受けられる。

そこで，今回我々はスクラブ粒子の物性と洗浄 機能を明確にし, 高洗浄力で皮膚安全性が高く,

$\dagger^{1}$ 1994.11.11 受理

$\dagger^{2} \quad$ T131 墨田区文花 2-1-3;2-1-3 Bunka, Sumida -ku, Tokyo 131 Japan.
ディリーに使用可能なスクラブ粒子の設計を行っ たので以下に報告する。

\section{2. 実験}

\section{1 試料}

スクラブ粒子としてポリエチレン（製鉄化 学), 架橋ポリアクリル酸ソーダ, 架橋ポリアク リル酸ラウリルエステル (以上花王), 活性剤水 溶液としてモノラウリルリン酸トリエタノールア ミン (MAP) (10 wt\%) (花王) を用いた。

\section{2 弾性率の測定}

弾性率の測定は，ポリマーシートを合成し，生 理食塩水に浸漬させたものを熱応力歪測定装置 TMA/SS 10 (セイコー電子工業(侏) を用い圧縮弾 性率として求めた。

その結果, ポリエチレンシートは $10^{9} \mathrm{dyne} /$ $\mathrm{cm}^{2}$, 架橋ポリアクリル酸ソーダのシートは, $10^{7} \mathrm{dyne} / \mathrm{cm}^{2}$, 架橋ポリアクリル酸ラウリルエス テルのシートは, $6 \times 10^{6} \mathrm{dyne} / \mathrm{cm}^{2}$ であった。(温 度 $20^{\circ} \mathrm{C}$, 湿度 $27 \%$, 振幅荷重土 $1 \mathrm{~g}$, 周期 0.05 $\mathrm{Hz}$, サインカーブ応力, 測定荷重 $3 \mathrm{~g}$ 圧縮プロ ーブ $\left.0.71 \mathrm{~mm}^{2}\right)$

\section{3 洗浄力の測定}

洗浄力の測定はモデル皮脂（Tabl-1）にマー 


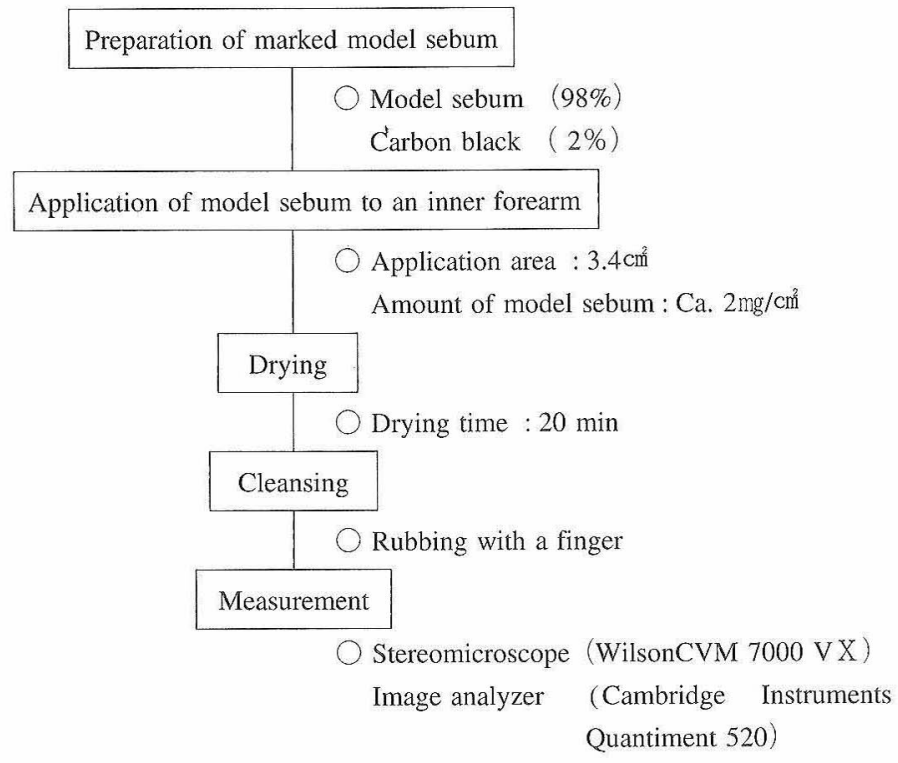

Fig.-1 Measurement method of remaining model sebum area ratio

Table-1 Composition of the model sebum

\begin{tabular}{|l|r|}
\hline Squalene & $8.0 \%$ \\
Myristyl myristate & $14.0 \%$ \\
Cotton seed oil & $7.2 \%$ \\
Cholesterol & $12.0 \%$ \\
Cholesterol palmitate & $4.0 \%$ \\
Lauric acid & $0.8 \%$ \\
Myristic acid & $6.4 \%$ \\
Palmitic acid & $24.8 \%$ \\
Stearic acid & $4.8 \%$ \\
Oleic acid & $18.0 \%$ \\
\hline
\end{tabular}

カーとしてカーボンブラック $2 \mathrm{wt} \%$ を分散させ たものを用い,これをとト前腕部内側に塗布 $\left(2 \mathrm{mg} / \mathrm{cm}^{2}\right)$ し，20 分間乾燥させた後，指によ る摩擦洗浄を行った。

さらに水洗，乾燥後，皮膚上に残ったモデル皮 脂を接触型実体顕微鏡 (Wilson CVM 7000 VX)

で撮影し，画像解析装置 (Cambridge Instrument Quantiment 520）により黑色面積率を求め, 残留 皮脂面積率とした（Fig.-1)。

皮溝面積率は，皮溝部をモデル皮脂で被覆した 時の黒色面積率として同上の装置で求めた。 (Fig.-2)。

洗浄率, 皮溝洗浄率は以下の式により算出した。
洗浄率 $(\%)=100$ 一残留皮脂面積率 $(\%)$ 皮满洗浄率 $(\%)=[($ 皮溝面積率一残留皮脂 面積率) /皮溝面積率] $\times 100$

\section{4 脱落コルネオサイト数の測定}

ヒト前腕部内側にコルネオサイト採取カップ市 をあてがい，カップの中にスクラブ粒子溶液を入 れてガラス棒で摚拌後, 溶液を取り出し赤血球計 算盤にて脱落コルネオサイト数を測定した。

\section{3. 結果と考察}

\section{1 スクラブ粒子の洗浄特性}

まず最初にスクラブ粒子の洗浄特性について検

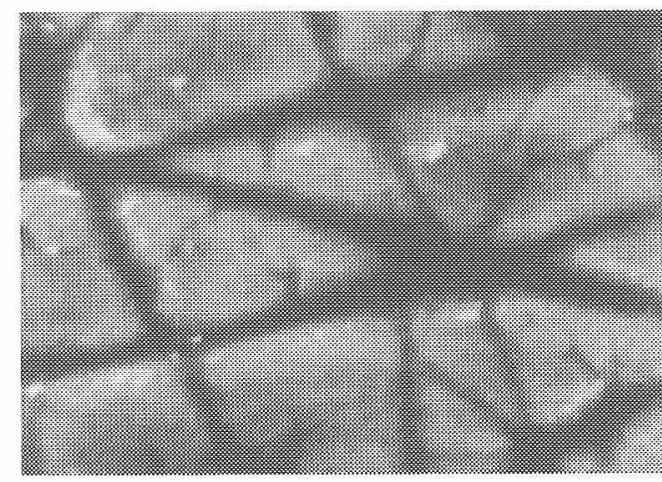

Fig. -2 Skin furrow covered with the model sebum 


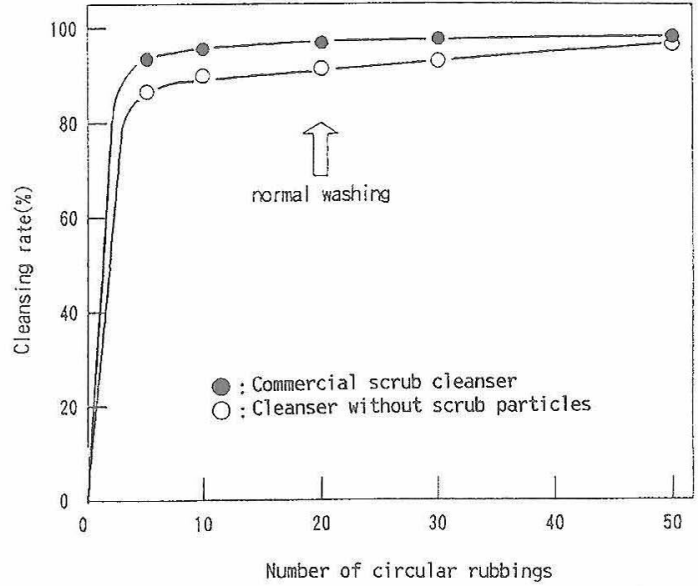

Fig. -3 Cleansing rate of cleansers with and without scrub particles

Cleansing rate $(\%)=100-$ remaining model sebum area ratio $(\%)$

討した。

Fig.-3は市販スクラブ洗顔料とそのスクラブ 粒子を除いた同洗顔料ベースの洗浄力を一定の力 の下に洗浄擋汼回数を变えて調べたものである。

どちらも洗浄擋拌回数が増加するに従い洗浄率 は上昇し飽和に達しており，スクラブ入り洗顔料 とベース洗顔料の洗浄率の差は少ないようにみえ る。

しかし，洗浄後の残存モデル皮脂の状態を調べ てみると皮溝中の皮脂の残り方が大きく異なって 扔り(Fig.-4)，スクラブ粒子が皮溝中の皮脂に 対して有効に働いていることがわかる。

そこで，己れを皮溝洗浄率で表してみると，ス クラブ粒子による洗浄効果の違いが明らかとなっ た (Fig. -5 )。

これはスクラブ粒子の洗浄特性が皮膚細部の污 れ除去力にあることを示しており，以後は特に皮 溝洗浄力に着目して検討を行った。

\section{2 スクラブ粒子の皮脂洗浄における最適物} 性

次にスクラブ粒子の洗浄力における最適物性を 調べるため，皮溝洗浄率をスクラブ粒子の弾性 率，粒径及び皮䖉上の存在個数の観点から倹討を 行った。

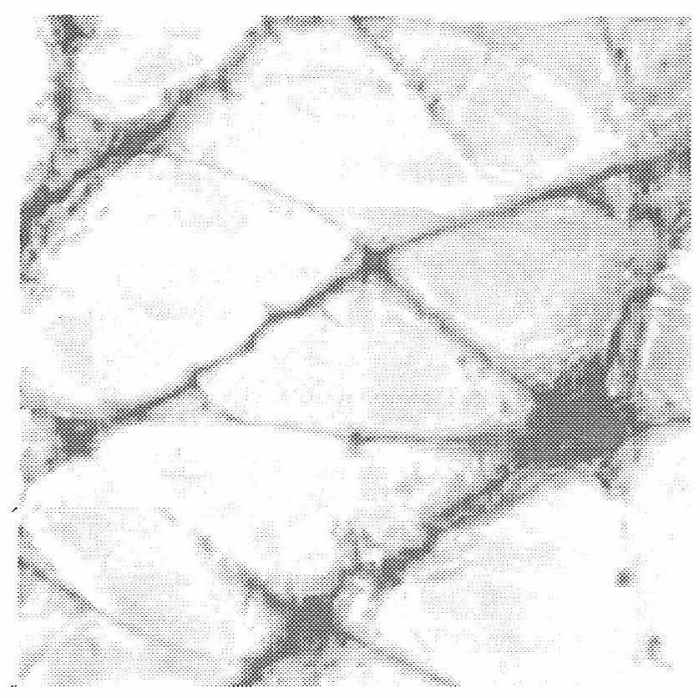

cleanser

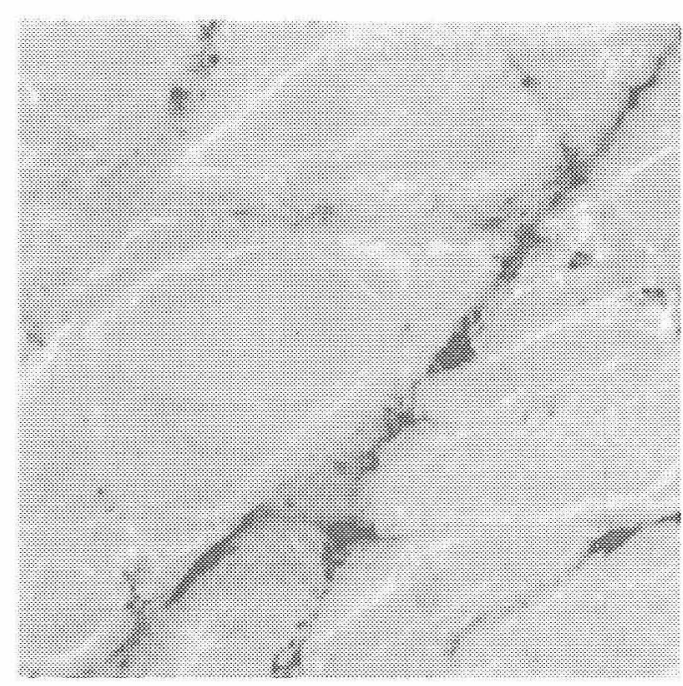

cleaner with scrub particles

Fig. -4 Photos of skin surface after washing with cleansers with and without scrub particles

Fig.-6は，一定粒径のスクラブ粒子配合溶液 で一定の皮膚在個数下で洗浄後の皮溝洗浄率と その粒子の弾性率の関係を表したグラフである。

スクラブ粒子の弾性率が大きくなるにつれて， 皮溝洗浄率は上昇する。

しかし，皮溝の弾性率 以上のスクラブ粒子の皮溝洗浄率は，ほとんど飽 和に達している。 


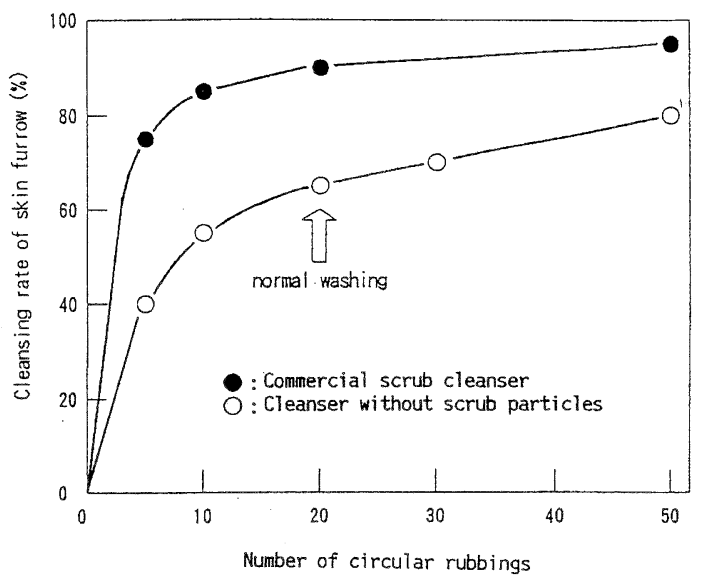

Fig. -5 Cleansing rate of skin furrow

Cleansing rate of skin furrow $(\%)$

$=[($ skin furrow area ratio $(\%)$-remaining modelsebum area ratio $(\%)) /$ skin furrow area ratio $(\%)] \times 100$

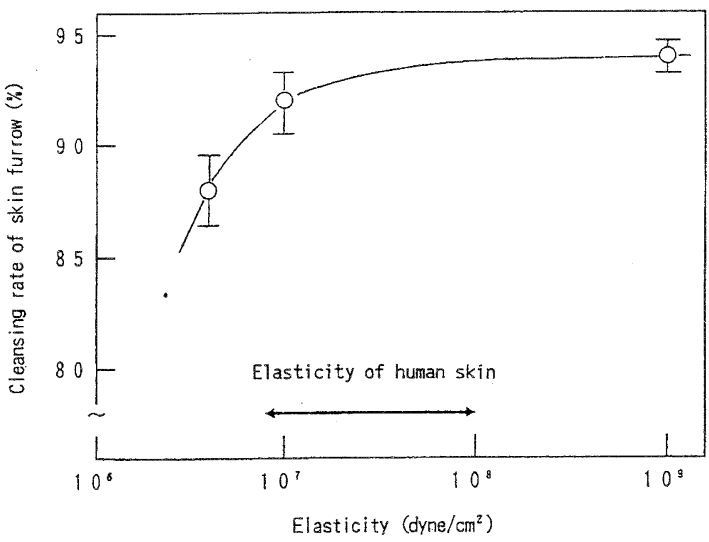

Fig. - 6 Dependence of cleansing rate of skin furrow on the elasticity of scrub particles Nember of circular rubbings : 20 times Diameter of scrub particles : 200-350 $\mu \mathrm{m}$ Number of scrub particles : 88 particles/ $\mathrm{cm}^{2}$

これはスクラブ粒子に十分な洗浄力を持たせる には対象とする被洗浄体と同様以上の弾性率を有 していれば良いことを示している。

次に $10^{7} \mathrm{dyne} / \mathrm{cm}^{2}$ の弾性率を持つスクラブ粒子 を, 一定数の皮膚存在個数下で, 皮清洗浄率とス
クラブ粒子の粒径（直径）の関係を調べた。

(Fig. -7 )。

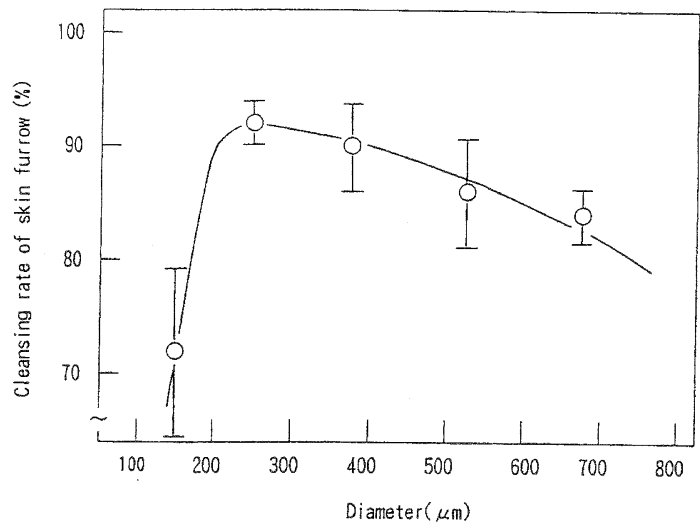

Fig. -7 Dependence of cleansing rate of skin furrow on the diameter of scrub particles Nember of circular rubbings : 20 times Diameter of scrub particles : $10^{7}$ dyne/ $\mathrm{cm}^{2}$

Number of scrub particles : 115 particles/ $\mathrm{cm}^{2}$

粒径が $200 \mu \mathrm{m}$ 以下の小さなスクラブ粒子では 皮溝洗浄率は低く，高洗浄力を得るためには一定

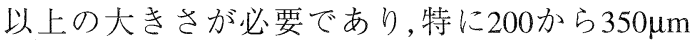
の粒径が最も望ましいという結果が得られた。

これは皮膚上の皮溝の集まっているくぼみ部や 毛穴部の皮脂は落とし難く（Fig.-8），この写真 の断面図をモデル化した図（Fig.-9）からもわか るように，このくぼみ部分を効果的に洗浄するこ とが必要であるためではないかと推測される。

Fig.-9のスクラブ粒子の粒径については実測 值，皮溝の深さについては文献值3を参考にし た。

次に $10^{7} \mathrm{dyne} / \mathrm{cm}^{2}$ の弾性率で, 粒径が200 350 $\mu \mathrm{m}$ のスクラブ粒子を用いてスクラブ粒子の皮膚上に おける存在個数と皮溝洗浄率の関係を調べた

(Fig.-10)。

皮膚上における存在個数が少ない時は, 皮溝洗 浄率は低く, 約 100 個 $/ \mathrm{cm}^{2}$ 以上の個数が存在す る時に，洗浄率はほぼ飽和に達する。

撹汼回数と皮膚存在個数は洗浄力の点で関係が あると思われる。通常の洗顔条件（洗浄摚挥回数 


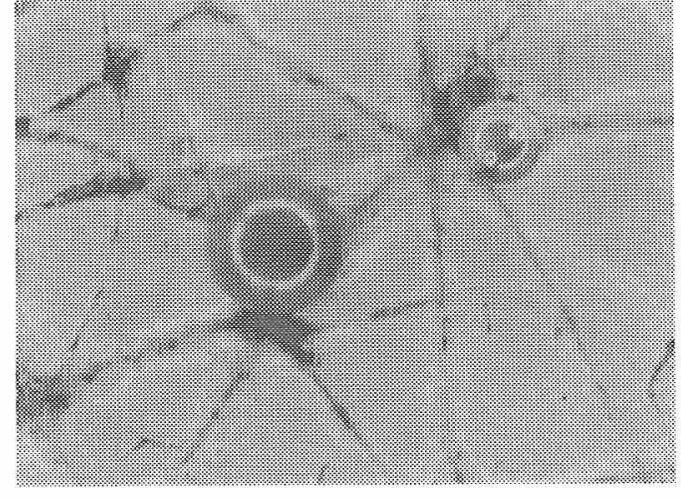

Fig. -8 Scrub particles on skin surface

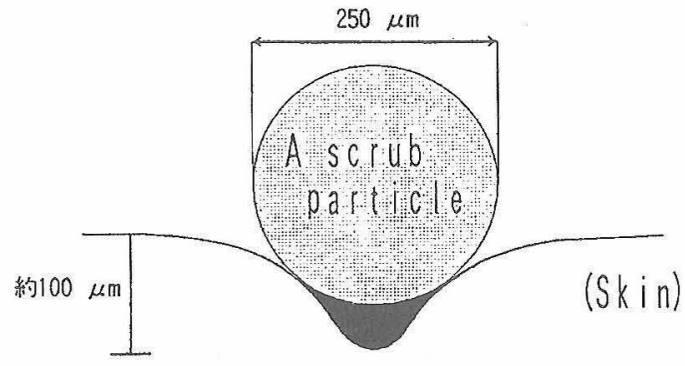

(Furrow)

Fig. -9 A scrub particle in a skin furrow

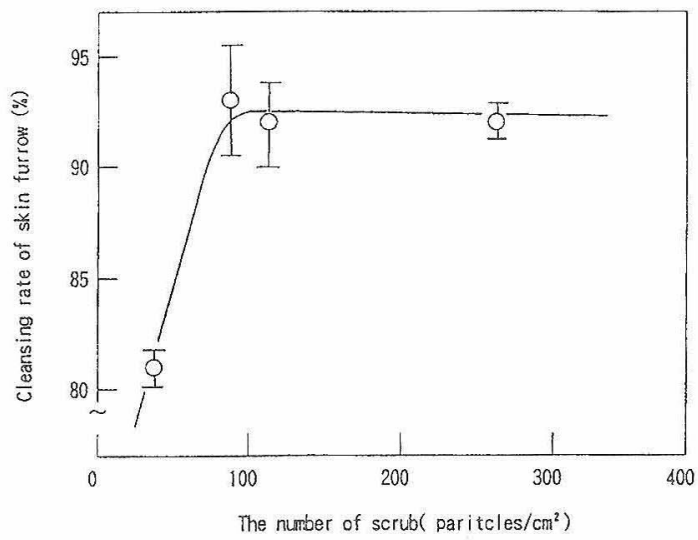

Fig. -10 Dependence of cleansing rate of skin furrow on the number of scrub particles Nember of circular rubbings : 20 times Diameter of scrub particles : $10^{7} \mathrm{dyne} / \mathrm{cm}^{2}$ Number of scrub particles : 200-350 $\mu \mathrm{m}$
20 回)では約 100 個 $/ \mathrm{cm}^{2}$ の個数が必要であった。

\section{3 污れの種類によるスクラブ粒子の洗浄特}

性

皮脂污れ除去に対する最適物性值を持つスクラ ブ粒子を用いて，スクラブ粒子が污れの種類によ り，どのような洗浄特性を示すか倹討した。

污れの種類は，油污れの代表としてモデル皮脂 を，粉体污れの代表としててカーボンブラックを用 い，洗浄片はスクラブ粒子を分散させた活性剤水 溶液と入れない活性剂水溶液とウオッシュオフタ イプの市販油性洗顔料の 3 種類で洗浄効果を調 ベた (Fig.-11)。

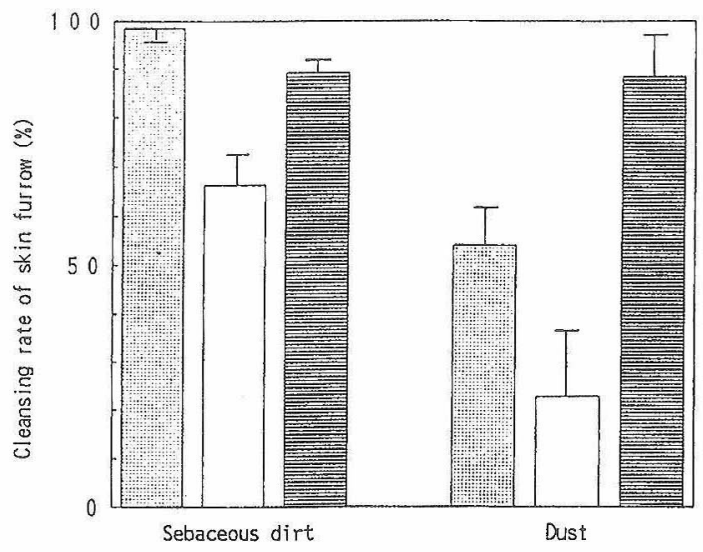

Fig. -11 Influence of dirt characters on cleansing ability (Number of circular rubbings : 20 times)

Composition of dirt (Oil / Carbon black)

Sebaceous $\operatorname{dirt}$.......................... $98 \% / 2 \%$

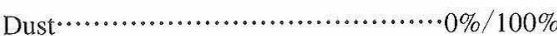

モデル皮脂污れに対する洗浄力は市販油性洗浄 剤が最も高かったが，粉体污れに対する洗浄力は スクラブ粒子を分散させた活性剂が最も高く，し かも污れの種類による洗浄力の低下は認められな かった。

これはスクラブ粒子が溶解あるいは分散させに くい污れを皮膚から剥離し, 界面活性郕に対して 分散助剤的に働いているためと考えられる。

\section{4 スクラブ粒子の皮膚への影響}

まず，スクラブ粒子の皮膚への影響を脱落コル 
ネオサイト数と落屑スコアにより調べることにし た。

Fig.-12 はスクラブ粒子を入れない活性剤水溶 液と, $10^{7}$ dyne $/ \mathrm{cm}^{2}, 10^{9}$ dyne $/ \mathrm{cm}^{2}$ の異なる弾性率 を持つスクラブ粒子をそれぞれ 5\% (w/w) 分散 させた活性剤水溶液を 3 種類準備し, 前述した 方法で測定した脱落コルネオサイト数とスクラブ 粒子の弾性率の関係を表したグラフである。

皮膚の弾性率に近い久クラブ粒子は，より大き い弾性率を持つものと比べて脱落コルネオサイト 数が少なく，それだけ皮膚への影響も少ないこと がわかる。

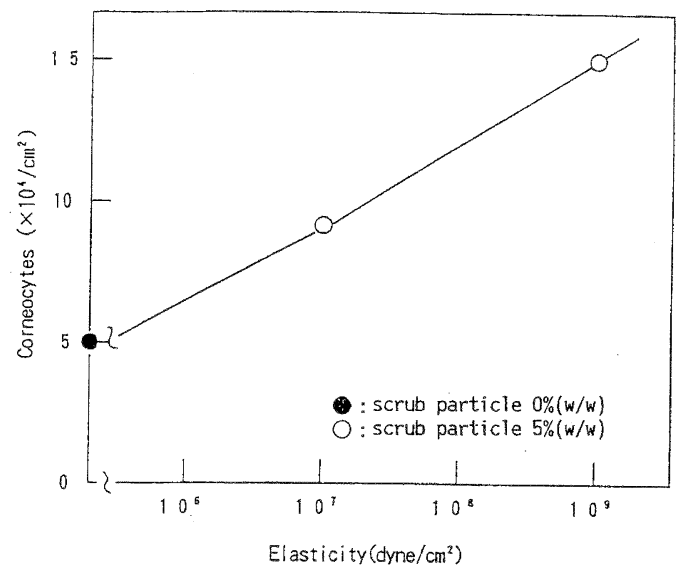

Fig. -12 Relationship between the number of removed corneocytes and the elasticity of scrub particles (Human forearm $(\mathrm{N}=4)$ )

次に前記と同様の 3 種類の溶液を用いて連続 4 日間 (1 日 2 回) ヒト前腕部内側を処理した後, 下記基準で肉眼でもって判定を㧍こなった

(Fig.-13)。

0 : 変化なし

0.5 : 完全に正常と判定しえない

1 : 乾燥し皮表が白く見えるが落屑は認め ない

皮膚とほほ同等の弾性率のスクラブ粒子分散活 性剂溶液はスクラブ粒子なしと落屑スコアはほと んど変らず，皮膚への影響が非常に少ない結果が 得られた。

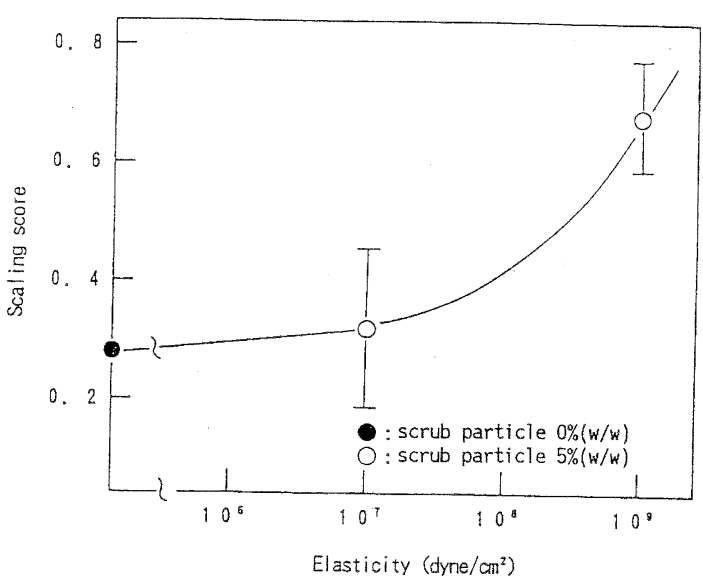

Fig. -13 Influence of elasticity of scrub particles on human skin (Human forearm $(\mathrm{N}=4)$ ) Treated twice a day for 4 succesive days Scaling score $\pm: 1.0,-<: 0.5,-: 0$

これらの脱落コルネオサイト数, 落屑の程度か らこの皮膚の弾性率に近いスクラブ粒子は非常に 低刺激であることがわかった。

さらに，この皮膚への影響が少ないスクラブ粒 子の長期にわたる肌への影響を調べることにし た。

顔の左（右）半分をスクラブ粒子配合の洗顔料 (MAP ベースで作製)，残りの右（左）半分をコ ントロールとしてスクラブ粒子なしの同洗顔料で 連日 1 日 2 回 9 週間 (7月中旬 29 月下旬) に わたって女性 4 人のボランティアによる半顔試 験をおこなった。

Fig.-14 は，ボランティアの額部と㚘部を定期 的に肉眼でもって前述と同基準で判定し，両部の 平均点の経過変化をスクラブ側とコントロール側 で表わしたグラフである。

両側の間には有意差は認められず，スクラブ粒 子が落屑を引き起こすことはなかった。

また，同時期同部位で，コンダクタンス測定も 行ったが有意差はなかった（Fig.-15）

次に前記ボランティアの洗顔一定時間後排出さ れる皮脂量を定期的に測定することでスクラブ粒 子の物理的刺激による皮脂線への影響を調べた。 


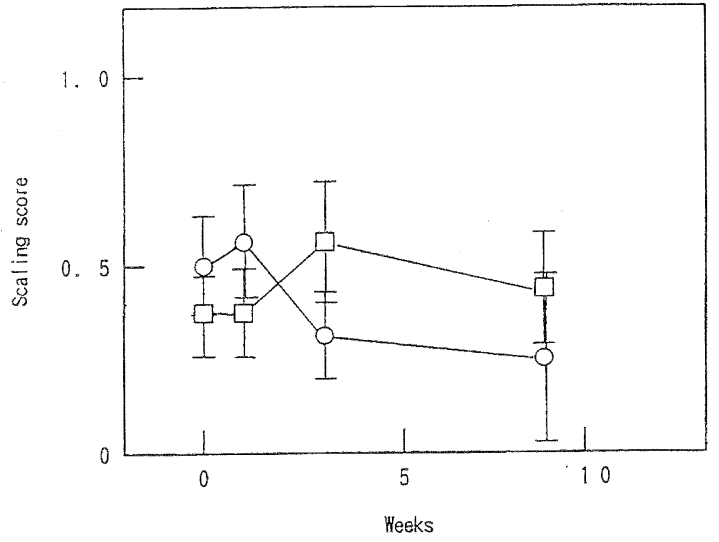

Fig. -14 Change in facial skin roughness ( 4 female volunteers, $21 \sim 26$ age) Treated twice a day with cleanser

$\square$ : cleanser without scrub particles $\bigcirc$ : cleanser with scrub particles Scaling score $\pm: 1.0,-<: 0.5,-: 0$

市販 MAP 系洗浄剂で洗顔後, 恒温室 $\left(20^{\circ} \mathrm{C}\right.$, $40 \%$ ）入室 30 分後 $1 \mathrm{~cm}$ 角のシガレットペーパ 一で額部より皮脂を 1 分間採取し，ガスクロマ トグラフィーによりスクアレンを定量したが，両 側の間には有意差は認められず，物理的刺激が皮 脂線を活性させることはなかった（Fig.-16）。

これらのデータにより,このスクラブ粒子の長 期連用使用による肌への悪影響は認められないこ とを確認した。

\section{4. 総括}

これまでの研究により，スクラブ粒子の機能が

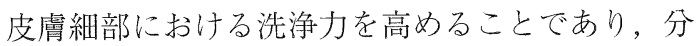
散除去機能により粉体污れに体して効果的である ことを明らかにした。

また，洗浄力とスクラブ粒子の物性值は関係が あり，洗浄力を最大に発揮するには，皮膚と同等 以上の弾性率 $\left(10^{7}\right.$ dyne $\left./ \mathrm{cm}^{2}\right)$ で, 粒径は皮溝の 起伏，毛穴の大きさ $(200 ~ 350 \mu \mathrm{m})$ と同等であ ることが必要で, かつ通常の洗顔条件では一定個 数以上皮膚上に存在する(約 100 個 $\left./ \mathrm{cm}^{2}\right)$ こと が必要である。

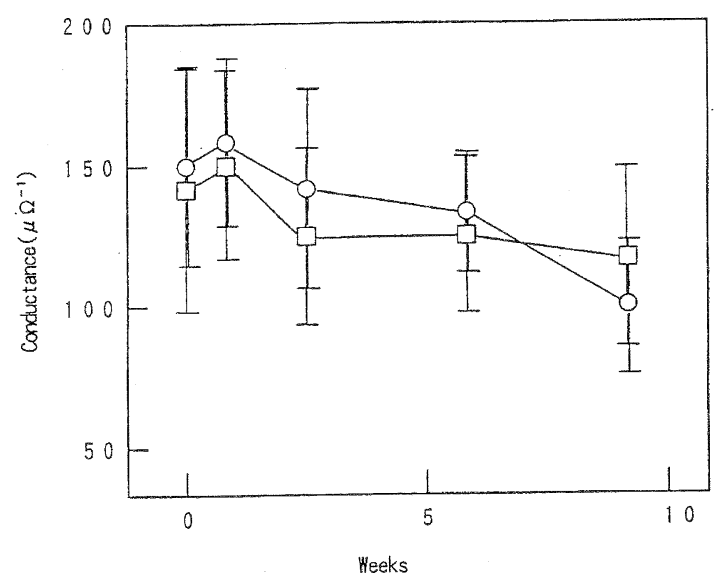

Fig. -15 Change in conductance of facial skin Treated twice a day with cleanser (4 female volunters, $21 \sim 26$ age)

$\square$ : cleanser without scrub particles

$\bigcirc$ : cleanser with scrub particles

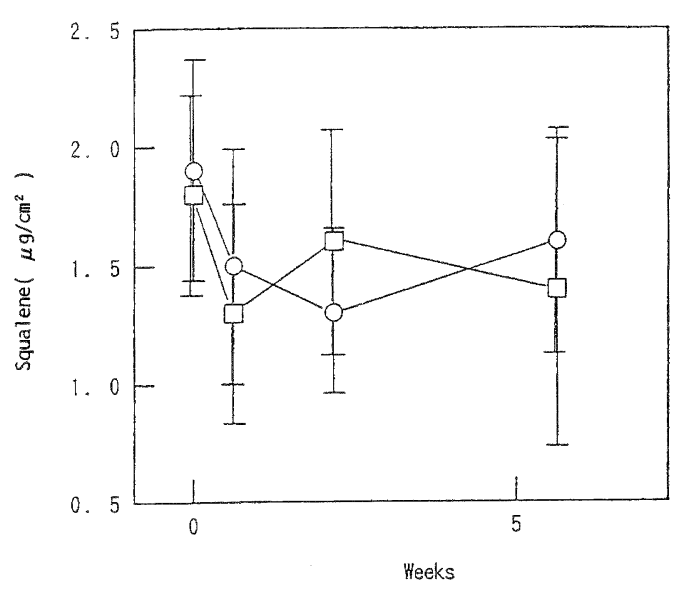

Fig. -16 Recovered sebum ( 4 female volunteers, $21 \sim 26$ age) Treated twice a day with cleanser

$\square$ : cleanser without scrub particles

$\bigcirc$ : cleanser with scrub particles

Sebum was collected for $1 \mathrm{~min}$. after 30 min. of washing

そして皮膚と同等の弾性率のスクラブ粒子 $\left(10^{7}\right.$ dyne $\left./ \mathrm{cm}^{2}\right)$ は皮膚に対して刺激が少なく，長期使 用可能なスクラブ粒子であることを確認した。 


\section{参考文献}

1) K. J. McGINLEY, R. R. MARPLES AND. G. PLEWIC, J. Invest. Dermat., 53,107(1969)
2) P. Agache. Arch. Dermatol. Res., 269, 221 (1980)

3) L. MARIE AND B. ANDERS, J. Soc. Cosmet. Chem., 41,111(1990)

\title{
The function and design of scrub particles on skin cleansing. $\dagger^{\dagger}$
}

\author{
Hirokazu Hamada, Yasushi Kajihara and Masatoshi Arisawa \\ Laboratories, Kao Corporation. $\dagger^{2}$
}

Facial scrub cleansers, the cleansing ability of which is raised by scrub particles have been popular recently. However, there are no documents which mention the function of scrub particles. We found by various experiments that scrub particles raise cleansing abilities of the narrow part of skin and have the dispersing and eliminating function of dirt.

We investigated relations between the cleansing ability and physical properties of scrub particles. It proved that the leasticity of particles was required to be more than that of human skin (about $10^{7}$ dyne $/ \mathrm{cm}^{2}$ ) for scrub particles. The size of particles has to be fitted for the skin furrow or hair pores $(200 \sim 350 \mu \mathrm{m})$. A certain number of particles are required to maximize its cleansing ability (more than about 100 particles $/ \mathrm{cm}^{2}$ ).

Scrub paticles whose elasticity is similar to that of skin turned out to be appropriately gentle to skin. They didn't damage skin even if we washed our faces every day with a facial cleanser containing the scrub particles. 